\title{
A.16 Toyo Bunko, Tokyo, Ms. No. $13^{34}$
}

A Nepalese paper manuscript of 354 leaves; undated..$^{35}$

1. Saptaśatikā-prajñāpāramitā(?)

2. Abhisamayālaṃkāra-prajñāpāramitopadeśaśāstra ${ }^{36}$

3. Pītavarṇa-prajñāpāramitā-dhāraṇī $[55,162]^{37}$

4. Prajñāpāramitā-dhāraṇī $[8,56]$

5. Sarvajñatākāra-dhāraṇī [53]

6. Uṣnịịacakravartī-nāma-dhāraṇī [50]

7. Anityatā-sūtra

8. Saptabuddha-stava

9. Șaṭpāramitā-hṛdaya-nāma-dhāraṇī [59]

10. Yakṣāṣțaka-sampannabuddhabhāṣita [64]

11. Jambhalajalendrasya-nāma-dhāraṇī [61]

12. Vasudhārā-nāma-dhāraṇī [62]

13. Amoghapāśa-nāma-hṛdaya-mahāyānasūtra [63]

14. Siṃhanādalokeśvarasya vyādhipraśamanī-dhāraṇī [64]

15. Avalokiteśvarasya mukhodgīrṇa-siddhinikā-nāma-dhāraṇī [65]

16. Sahasrabhujalokeśvara-dhārạ̣ī [66]

17. Avalokiteśvarasya nīlakaṇtha-nāma-dhāraṇī [67]

18. Sahasrāvartā-nāma-dhāraṇī [68]

19. Șaḍakṣarī-mahāvidyā-nāma-dhāraṇī [69]

20. Bhadracari-mahāpraṇidhānarāja [70]

21. Mokṣapada-nāma-dhāraṇī [71]

22. Abhayaṃkarī-nāma-dhāraṇī [72]

23. Māṇibhadra-nāma-dhāraṇi [73]

24. Vajrapāṇi-mahārakṣā-nāma-dhāraṇī [49]

25. Herukasya sarvarogapraśamanī-nāma-dhāraṇī [144]

26. Vairocana-nāma-dhāraṇī [3]

34 After Kaneko et al. 1979 with minor standardizations. Folio numbers are given there. I have not been able to consult the original manuscript or any reproductions. Most titles are also listed in Tsukamoto et al.: 150-175. Corresponding text numbers in Cambridge Ms. Add. 1326 are given in square brackets (there is a chance of inconsistencies in the case of texts which appear by the same title more than once).

35 Kaneko et al. 1979: 169.

36 Folios 1-31 are missing and thus the presence of the Saptaśatikā is a conjecture. The end of the Abhisamayālaṃkāra survives. For such beginnings cf. Matsunami 1965: 148-149 and NGMPP E 614-3 in Appendix 13.

37 Note that in Kaneko et al. 1979 the numbering of the texts in the manuscript begins here. 
27. Akṣobhya-nāma-dhāraṇī [4]

28. Ratnasambhava-nāma-dhāraṇi [5]

29. Amitābha-nāma-dhāraṇī [6]

30. Amoghasiddhi-nāma-dhāraṇī [7]

31. Durgatipariśodhanī-nāma-dhāraṇī [45,74]

32. Gāthādvaya-nāma-dhāraṇī [43]

33. Cundābhagavatī-dhāraṇī [75]

34. Hutāśanatejo-nāma-dhāraṇi [37]

35. Bhaiṣajyarājaśodhana-nāma-dhāraṇī [38]

36. Mañjuśrīpratijñā-nāma-dhāraṇī [58]

37. Padmahasta-dhāraṇī [17]

38. Sarvamañgala-nāma-dhāraṇī [39]

39. Karṇajāpā-nāma-dhārạ̣ī [40]

40. Sarvapāpadahana-nāma-dhāraṇī [41]

41. Suvarṇaprabhāsottame sūtrendrarāje sarvabuddhabodhisattva-nāma-saṃdhāraṇīparivarta [16]

42. Mahāpratisarā-mahāvidyā-dhāraṇī [76]

43. Pratisarā-kalpa-dhāraṇi [77]

44. Mahāsāhasrapramardanī-nāma-vidyā-dhāraṇī [78]

45. Mahāmāyūrī-vidyārājñ̄i-nāma-dhāraṇī [79]

46. Mahās̄îtavatī-nāma-vidyā-dhāraṇī [80 $]^{38}$

47. Tathāgataguhyakā-nāma-dhāraṇī [14]

48. Bodhisattvacaryāprasthāna-daśabhūmīśvara-nāma-mahāyānasūtraratnarāja [10]

49. Sapane-vidyā-dhāraṇī [84]

50. Jātismara-nāma-dhāraṇī [36]

51. Jātismara-nāma-dhāraṇī [36]

52. Parṇaśavarī-mahāmārīpraśamanī-nāma-dhāraṇī [85]

53. Gaṇḍavyūhasya-nāma-dhāraṇī [9]

54. Hemāñga-/Hemagāthā-nāma-dhāraṇī [86]

55. Guhyeśvaraparama-tantra-yantra-mantra-aprameyaphala

56. Maitreyapratijñā-nāma-dhāraṇī [87]

57. Mañjughoṣakṛti-praṇidhānarāja [88]

58. Tārāpratijñā-dhāraṇī [89]

59. Saddharmapuṇḍāikasya mantra-dhāraṇi [13]

60. Dhvajāgrakeyūra-nāma-dhāraṇī [90]

61. Gāthādvaya-nāma-dhāraṇī [43]

62. Șaṇmukhī-nāma-dhārạ̣ī [44]

38 Two folios are missing here. 
63. Mahāmāyāvijayavāhinī-nāma-dhāraṇī [91]

64. Saddharmalan̉kāvatāra-mahāyānasūtra-nāma-dhāraṇī [12]

65. Lalitavistare trapuṣabhallikaparivartanāya-bhāṣita-kalyāṇavyākya [15]

66. Kurukullā-nāma-dhāraṇī [95]

67. Jāñgulī-nāma-dhāraṇī

68. Mārīcī-nāma-dhāraṇī [92]

69. Vajrasarasvatī-sādhana [93]

70. Vajravairocanī-stava [96]

71. Śākyamunīnām viśeșa-dhāraṇī [35] 39

72. Ekajațā-nāma-dhāraṇī [113]

73. Daśakrodhamahābhairava-nāma-dhāraṇī [114]

74. Nāmasaṃīiti-dhāraṇī [57,115]

75. Āryāvalokiteśvarasya mukhodgīrnā-siddhinikā-nāma-dhāraṇī [116]

76. Amṛtabhakṣā-nāma-dhāraṇī [117]

77. Aștamahābhayaharaṇatārā-nāma-dhāraṇī [118]

78. Buddhabhaț̣ārakasya dhāraṇī [119]

79. Yogāmbarasya karmarājaviśuddhi-nāma-dhāraṇī [120]

80. Sarvalokeśvara-dhāraṇī [121]

81. Khasarpaṇa-nāma-dhāraṇī [122]

82. Arapacanamañjuśrī-sādhana-nāma-dhāraṇī [123]

83. Maitreya-nāma-dhāraṇī [124]

84. Saddharmapāṭha-dhāraṇī [125]

85. Vajratārā-nāma-dhāraṇī [126]

86. Ugratārā-nāma-dhārạ̣ī [127]

87. Daśakrodhānāṃ dhāraṇī [128]

88. Lokapālānām nāmnāṃ dhāraṇī [129]

89. Gaganākṣepavajrayogīnī-nāma-dhāraṇī [130]

90. Raktayamāri-nāma-dhāraṇī [131]

91. Prasannatārā-nāma-dhāraṇī [132]

92. Mahābhairavasya dhāraṇī [133]

93. Siddhivighneśvara-dhāraṇī [134]

94. Mahākālasya dhāraṇī [135]

95. Gaṇeśasya șoḍaśa-nāma [136]

96. Vasudhārāṇy-upadeśa [137]

97. Puṇyavivardhana-nāma-dhāraṇī [138]

98. Sạ̣akṣarī-nāma-dhāraṇī [139]

99. Āryāvalokiteśvara-stotra [140]

39 Six folios are missing here. 
100. Vajragandhārī-nāma-dhāraṇī [141]

101. Kālacakranibaddha-dhāraṇī [142]

102. Hevajradhāraṇapūjā-vidhi [143]

103. Mahāsarasvatī-dhāraṇī [94]

104. Mahāpratisarā-dhāraṇī [145]

105. Mahāpratisarāyā sādhana [146]

106. Mahāmāyūrī-dhāraṇī [147]

107. Mahāsāhasrapramardanī-sādhana [148]

108. Mahāmantrānusāriṇī-sādhana [149]

109. Mahāśītavatī-sādhana-nāma-dhāraṇī [150]

110. Pañcarakṣā-mahādevyā sādhana [151]

111. Hastapūjā-vidhāna [152]

112. Nairātmā-sādhana-dhāraṇi [153]

113. Vajrahūṃkārabhairavasya dhāraṇī [154]

114. Hayagrīva-dhāraṇī [155]

115. Hayagrīvabhairavasya dhāraṇī [156]

116. Bhūtaḍāmara-saṃkṣipta-dhāraṇī [157]

117. Gaganātmyaśuklavarṇavajravārāhī-nāma-dhāraṇi [158]

118. Vajrayoginī-nāma-dhāraṇī [159]

119. Vajraśrnnikhalā-dhāraṇī [160]

120. Saṃkṣipta-dvibhujaherukasya-nāma-dhāraṇī [161]

121. Vasudhārā-dhāraṇī [165]

122. Sitātapatrāparājitā-nāma-dhāraṇī [166]

123. Vajracarcikā-nāma-dhāraṇī [167]

124. Dhvajāgrakeyūrā-sādhana-dhāraṇī [168]

125. Uṣṇịsavijayā-sādhana-dhāraṇī [169]

126. Mahāmāyā-nāma-dhāraṇī [170]

127. Caṇḍamahāroṣaṇa-dhāraṇī [172]

128. Mahāsamvvarasya karmarājaviśuddhi-nāma-dhāraṇī [173]

129. Hevajra-nāma-dhāraṇī [174]

130. Svalpākṣarā-bhagavatī-prajñāpāramitā [164]

131. Trailokyavijayā-nāma-dhāraṇī [175]

132. Lokātīta-stava [176]

133. Aparimitāyur-nāma-mahāyānasūtra [47]

134. Sarvatathāgatoṣṇisasasitātapatrā-nāmāparājitā-pratyañgirā-mahāvidyārājñī [83]

135. Vasundhārā-nāma-stotra-samyaksambuddhabhāṣita [97]

136. Vajravidāraṇī-nāma-dhāraṇī-hṛdaya-mūlasūtra [98]

137. Gaṇapati-hṛdaya [99]

138. Uṣṇiṣavijayā-nāma-dhāraṇī [100] 
139. Pañcaviṃśatikā-prajñāpāramitā-hṛdaya [101]

140. Mārīcī-nāma-dhāraṇī [102]

141. Grahamātṛ̂ā-nāma-dhāraṇī [103]

142. Grahamātṛkā-nāma-dhāraṇī [177]

143. Navagraha-stuti

144. Prajñāpāramitayārambhakṛta-dhāraṇī-saṃgraha

145. Vāgīśvarapūjāvidhi-stotra

146. Gośṛngaparvate svayambhūcaityabhaț̣ārakoddeśa ${ }^{40}$

147. Śrīvasudhārādevīpūrvakathāvratadharmasampūrṇanandimukhāśvaghoșāvadāna

148. Phalāphala-hṛdaya

149. Triskandhaka

150. Nīlatantre tārāșțaka-stotra

151. Vajravārāhī-dvādaśa-stuti

152. Nāgapūjā-stotra

153. Nis̄ābhairava-dhāraṇī

154. Suvarṇaprabhāsottamasūtrendrarāje sarasvatīdevīparivarta-nāma-dhāraṇī-stava

155. Suvarṇaprabhāsottamasūtrendrarāje śrīmahādevīparivarta-nāma-dhāraṇī-sūtra

156. Suvarṇaprabhāsottamasūtrendrarāje sarvabuddhabodhisattva-nāma-samdhāraṇī-sūtra [16]

157. Rāhavyagrahaśānti-svasti-upadrava-dhāraṇī

158. Ketugrahaśānti-dhāraṇī

159. Vighnāntaka-stava-stotra

160. Prathamākṣarasarvajñamitrasamyuktașaḍakṣara-stava

161. Prajñāpāramitā-hṛdaya

162. Nīlasarasvatī-dhāraṇī

163. Ādityadvādaśasūrya-nāma-dhāraṇī [111]

164. Tārāyā daśākṣaravidhāna-dhāraṇī-sūtra

165. Durgottāraṇī-sādhana-dhāraṇī

166. Vajravidāraṇa-hṛdaya-mantra-nāma-dhāraṇī-vidyārājñ̄isomacandra-nāma-dhāraṇī [98]

167. Nairātmādevī-așțaka-stava

168. Mahogratārā-stuti

169. Dharmacakrapravartana-nāma-dhāraṇī

170. Tārābhațạārikāyā nāmāṣțottaraśataka-buddhabhāṣita

40 Cf. von Rospatt 2015: 827. 
171. Samyaksambuddhavairocanabhāṣita bhagavatyai āryatārādevyā namaskāraikavimśati-nāma-tantra

172. Māyājālaṣoḍaśasāhasrikān mahāyogatantrāntaḥpātisamādhijālapaṭalād bhagavattathāgataśākyamunibhāṣitā bhagavanto mañjuśrījñānasattvasya paramārthā-nāmasaṃgīti [57]

173. Vajrasattvakāyabhava-tathāgatavyāpti-śūnyanirañjana-tattva / Vajrasattvakāyasya tathāgatavyāptaśata

174. Cintāmaṇivairocana-nāma-dhāraṇī

175. Viśvabhadra-nāma-tathāgata-nāma-dhāraṇī

176. Ratnarāja-nāma-tathāgata-dhāraṇi

177. Vākavajra-nāma-tathāgata-dhāraṇī

178. Amogha-nāma-tathāgatasya dhāraṇī

179. Tārā-nāma-dhāraṇī

180. Rocanā-nāma-dhāraṇī

181. Māmakī-nāma-devī-nāma-dhāraṇī

182. Pāṇḍaātārādevī-nāma-dhāraṇī

183. Māyā-lokeśvara-nāma-dhāraṇī

184. Padmapāṇilokeśvara-nāma-dhāraṇī

185. Amoghapatilokeśvara-nāma-dhāraṇī

186. Ānandādilokeśvara-nāma-dhāraṇī

187. Cugamalokeśvara-nāma-dhāraṇī

188. Halāhalalokeśvara-nāma-dhāraṇī

189. Sarvalokeśvara-nāma-dhāraṇī [121]

190. Mañjuvajra-nāma-dhāraṇī

191. Sarvākārajñatā-nāma-dhāraṇī

192. Ekaślokātipakāla-nāma-dhāraṇī

193. Sarvabuddhacūọāmaṇi-nāma-dhāraṇī

194. Prasannatārā-nāma-dhāraṇī [132]

195. Siddhivighneśvara-nāma-dhāraṇī [134]

196. Vajravīramahākālasya-nāma-dhāraṇī

197. Caturdiglokapāla-nāma-dhāraṇī

198. Saddharmapāṭha-dhāraṇī [51,125]

199. Bhṛkuṭitārā-nāma-dhāraṇī

200. Samādhiyogāmbara-dhāraṇī

201. Jñānadevī-nāma-dhāraṇī

202. Sậ̣yoginī-nāma-dhāraṇī

203. Māyācakra-tantra

204. Sarvabuddhabhaț̣ārakasya-nāma-dhāraṇī [34,119]

205. Cundābhaț̣ārikā-nāma-dhāraṇī / Cundābhațțārikāyā rakșāmantra-dhāraṇī [110] 
206. Vajravidāraṇī-nāma-dhāraṇī [98]

207. Vajratārā-nāma-dhāraṇī [126]

208. Mārīcī-nāma-dhāraṇī [92,102]

209. Vāgīśvarasya dvādaśākṣara-nāma-dhāraṇī /

Dvādaśākṣaramūla-nāma-dhāraṇī

210. Padmottama-nāma-dhāraṇī

211. Śaniścarasya dvādaśa-nāma-stotra [180]

212. Hūṃkārasambhava-nāma-dhāraṇī

213. Sarvapāpadahana-nāma-dhāraṇī [41]

214. Cintāmaṇilokeśvara-nāma-dhāraṇī [33,109]

215. Sarvatrālana-mantra-dhāraṇī

216. Caityapungavasya hṛdaya-nāma-dhāraṇi

217. Pañcajinadharmadhātuvāgīśvara-dhāraṇī / Dharmadhātuvāgīśvara-saṃkṣipta

218. Vijayavāhinī-nāma-dhāraṇī [91]

219. Pañcākșara-stotra

220. Oṃkāra-nāma-dhāraṇi

221. Hūṃkāra-nāma-dhāraṇī

222. Trāṃkāra-nāma-dhāraṇī

223. Hrīṃkāra-nāma-dhāraṇī

224. Svaṃkāra-nāma-dhāraṇī

225. Vajradhātumaṇụala-dhāraṇī

226. Vajraphaṭkṣaṇa-nāma-dhāraṇī

227. Vajrarāja-nāma-dhāraṇi

228. Vajrasādhya-nāma-dhāraṇī

229. Vajrateja-nāma-dhāraṇī

230. Vajraketu-nāma-dhāraṇī

231. Vajrahāsa-nāma-dhāraṇī

232. Vajradharma-nāma-dhāraṇī

233. Uṣnịṣamahābala-nāma-dhāraṇī

234. Samādhiyogāmbarasya-nāma-dhāraṇī

235. Sộaśayoginī-stotra

236. Cauṣaștiyoginī-nāma-stotra

237. Samādhiyogāmbarasya-nāma-dhāraṇī

238. Dhūmāñgārī-nāma-dhāraṇī

239. Kāminīśrīdevī-nāma-dhāraṇi ${ }^{41}$

240. Sukhāvatīvyūha-nāma-dhāraṇī

41 One folio is missing here. 
241. Harasiddhi-nāma-dhāraṇī

242. Padmapāṇilokeśvarasya stotra

243. Avalokiteśvarasya dharmarājakṛtāṣțottaraśata-nāma-stotra

244. Navanāgasya hṛdaya-dhāraṇī

245. Samvvara-nāma-dhāraṇi

246. Vajravārāhyā-nāma-stotra

247. Sarasvatīdevī-stotra

248. Lakṣmīdevī-dhāraṇī

249. Așțalokapāla-stotra

250. Śanaiścara-dvādaśa-nāma-pāṭha

251. Dvibhujamahāsaṃvara-nāma-dhāraṇī

252. Pañcamahārāja-nāma-dhāraṇī

253. Aṣțamātṛkā-stotra

254. Bodhisattvaṣoḍaśa-nāma-dhāraṇī

255. Navagrahadevatāya paṭhādi

256. Padmanṛtyanātheśvara-nāma-dhāraṇī

257. Pratyālịụhapada-nāma-dhāraṇī

258. Jānidhapada-nāma-dhāraṇi

259. Madapaṇụa-nāma-dhārạ̣i

260. Ekapada-nāma-dhāraṇi

261. Vajrakarṣaṇapada-dhāraṇi

262. Vajravīrāsanapada-dhāraṇī

263. Amoghapada-dhāraṇī

264. Sarvāpāyajaha-dhāraṇī

265. Vajratuṇ̣̂abhipada-dhāraṇī

266. Samantabhadra-nāma-dhāraṇī [20]

267. Sūrya-dhāraṇī

268. Candra-dhāraṇī

269. Sarvavighnaharaṇī-nāma-dhāraṇi 